\title{
FUNGSI BEA METERAI DALAM SURAT PERJANJIAN
}

\author{
Siti Nurdiyah Fauza Tuanaya \\ Program Studi Magister Kenotariatan \\ Fakultas Hukum, Universitas Diponegoro \\ liatuanaya@gmail.com
}

\begin{abstract}
This paper with the title of the Stamp Duty Function is very important to realize the duty stamp duty in the agreement to the public. The purpose of this paper is to know and understand the function of the stamp duty in the agreement, to know and understand the validity of the letter of agreement which is not equipped with the stamp duty, and to know and understand the validity of the agreement without the stamp duty. In this paper the author uses normative juridical approaches. That the use of stamp duty is not a valid indicator or invalid of an agreement letter.
\end{abstract}

Keyword: stamp duty; tax; letter of agreement

\begin{abstract}
Abstrak
Penulisan dengan judul Fungsi Bea Meterai sangatlah penting untuk menyadarkan fungsi bea meterai dalam surat perjanjian kepada masyarakat. Penulisan ini bertujuan untuk mengetahui dan memahami fungsi bea meterai dalam surat perjanjian, untuk mengetahui dan memahami sah atau tidaknya surat perjanjian yang tidak dilengkapi bea meterai, dan untuk mengetahui dan memahami sah atau tidaknya surat perjanjian yang tidak dilengkapi bea meterai. Dalam penulisan ini penulis menggunakan metode pendekatan yuridis normatif. Bahwa penggunaan bea meterai bukanlah indikator sah atau tidak sahnya surat perjanjian.
\end{abstract}

\section{Kata kunci : bea; meterai; surat perjanjian}

\section{A. Pendahuluan}

Perjanjian dalam Kitab Undang-Undang Hukum Perdata diatur pada pasal 1313. Suatu persetujuan adalah suatu perbuatan dengan mana satu orang atau lebih mengikatkan dirinya terhadap satu orang lain atau lebih. Jika kita telaah kembali, pada pasal 1313 Kitab Undang-Undang Hukum Perdata tersebut jelas menyatakan bahwa hanya satu pihak saja yang aktif mengikatkan dirinya, menandakan bahwa perjanjian yang dimaksud hanyalah perjanjian sepihak. Maka menurut penulis, perjanjian adalah suatu perbuatan hukum yang memiliki nilai ekonomis dimana masingmasing pihak saling mengikatkan diri satu dengan lainnya. Kemudian suatu perjanjian harus memenuhi syarat sahnya perjanjian. Syarat sahnya perjanjian diatur dalam pasal 1320 Kitab Undang-Undang Hukum Perdata. 
Untuk sahnya persetujuan-persetujuan diperlukan empat syarat :

1. Sepakat mereka yang mengikatkan dirinya;

2. Kecakapan untuk membuat suatu perikatan;

3. Suatu hal tertentu;

4. Suatu sebab yang halal.

Dengan terpenuhinya syarat tersebut, tidak menutup kemungkinan akan timbulnya permasalahan hukum di masa yang akan datang.

Dalam penulisan artikel ini penulis menggunakan beberapa teori, diantaranya Teori Kemanfaatan dimana kemanfaatan merupakan salah satu tujuan hukum. Hukum yang baik adalah yang mendatangkan kemanfaatan bagi manusia. Kemanfaatan dapat juga diartikan kebahagiaan (happiness), sehingga dalam pelaksanaan dan penegakan hukum, masyarakat mengharapkan adanya kemanfaatan. Karena hukum untuk manusia, maka pelaksanaan/penegakannya haruslah memberi manfaat atau kegunaan bagi masyarakat, jangan sampai justru akan berakibat sebaliknya, penegakan hukum malah menimbulkan keresahan masyarakat. (Margono, 2019). Jika dianalisis menggunakan Teori Kemanfaatan, jelas meterai memiliki nilai manfaat bagi suatu surat perjanjian. Kemudian Teori Kepastian Hukum dimana masyarakat mengharapkan adanya kepastian hukum, karena dengan adanya kepastian hukum masyarakat akan lebih tertib. Hukum bertugas menciptakan kepastian hukum karena tujuannya adalah untuk ketertiban masyarakat. Jika dianalisis menggunakan Teori Kepastian Hukum maka jelas penggunaan meterai pada surat perjanjian dapat memberikan kepastian hukum terhadap surat perjanian tersebut di muka pengadilan apabila suatu saat surat perjanjian tersebut dipermasalahkan. Selain teori-teori hukum tersebut diatas, dalam penelitian ini didukung pula dengan penggunaan Konsep Hukum Perjanjian dimana ada 4 syarat sahnya suatu perjanjian, seperti yang telah disebutkan di paragraf pertama.

Lazimnya dalam praktek keseharian, setiap surat perjanjian menyertakan meterai. Masyarakat cenderung menggunakan meterai sebagai indikator dalam menentukan sah atau tidaknya suatu perjanjian. Hal ini dikarenakan banyak masyrakat yang belum mengetahui fungsi bea meterai dalam surat perjanjian, masyarakat tidak mengerti apakah surat perjanjian yang tidak dilengkapi dengan bea meterai dapat dinyatakan sah kemudian masyarakat juga tidak mengetahui bagiamana kekuatan yuridis surat perjanjian yang dilengkapi bea meterai apabila terjadi sengketa di pengadilan. 
Berdasarkan uraian-uraian tersebut diatas, penulis tertarik untuk membahas permasalahanpermasalahan yang ada yaitu mengenai fungsi bea meterai yang sesungguhnya dalam surat perjanjian, bagaimana keabsahan surat perjanjian tanpa bea meterai, dan bagaimana kekuatan yuridis bea meterai apabila terjadi sengketa di pengadilan. Semua permasalahn tersebut akan dibahas ke dalam penulisan artikel yang berjudul "Fungsi Bea Meterai Dalam Surat Perjanjian".

\section{B. Pembahasan}

\section{Fungsi Bea Meterai dalam Surat Perjanjian}

Pada zaman Kolonial Belanda, ada banyak lurah yang dipecat oleh Pemerintah Belanda karena dianggap lalai dalam menjalankan tugasnya untuk memungut bea meterai atas dokumen yang terhutang. Sebelum dipecat, lurah tersebut diarak mengelilingi pasar dengan tangan terborgol sehingga menjadi bahan tontonan warga masyarakat. Kejadian ini menjadi bahan pembelajaran secara efektif kepada masyarakat yang secara mayoritas masih buta huruf, tidak memiliki kemampuan membaca staatsblad 1817 No. 50 (Pemungutan Bea Meterai 1817) ataupun staatsblads 1885 No. 131 (Ordonansi pemungutan Bea Meterai di Hindia-Belanda) ataupun staatsblad 1921 No.498 (Aturan Bea Meterai 1921/ zegelverordening 1921). (Pamungkas, 2017)

Dengan adanya kejadian tersebut masyarakat membuat kesimpulan sendiri, mereka beranggapan bahwa suatu dokumen atau surat perjanjian yang tidak disertai meterai adalah tidak sah. Salah satu budaya yang tumbuh dalam masyarakat adalah anggapan atau persepsi bahwa surat perjanjian adalah sah jika surat perjanjian tersebut lunas bea meterai. Jika dihubungkan dengan kepatuhan pajak, maka budaya tersebut adalah baik.

Dalam rangka pembangunan nasional, peran serta segenap warga masyarakat perlu ditingkatkan dalam menghimpun dana pembiayaan yang sumbernya sebagian besar dari sektor perpajakan, maka salah satu cara mewujudkannya ialah dengan memenuhi kewajiban pembayaran Bea Meterai atas dokumen-dokumen tertentu yang digunakan.

Bea Meterai adalah pengenaan pajak atas dokumen, dan memberikan kekuatan yang sempurna, dalam arti apabila telah dibayarkan bea meterianya maka akta tersebut terhindar dari sanksi administratif yang diatur dalam Undang-Undang Bea Meterai. Dokumen oleh Siahaan didefinisikan sebagai kertas yang berisikan tulisan yang memiliki arti dan maksud 
tentang perbuatan, keadaan, atau kenyataan bagi seseorang dan atau pihak-pihak yang berkepentingan. (Arief, 2011)

Kata "Bea" digunakan sebagai istilah khusus untuk menyatakan "pajak tidak langsung”. (Soemitro, 1992) Pajak tidak langsung adalah pajak yang dikenakan secara insidental yaitu pada saat dipenuhinya Tatbestand (keadaan, perbuatan, peristiwa) yang ditentukan dalam undang-undang pajak, tidak mempunyai kohir atau daftar dan jumlahnya dapat dilimpahkan kepada orang lain. (Soemitro, 1991)

Jika dihubungkan dengan kesadaran hukum, anggapan atau budaya mengenai suatu dokumen atau surat perjanjian tanpa meterai adalah tidak sah, kurang bagus nilainya. Perlu diperhatikan bahwa sah atau tidaknya suatu perjanjian tidak ditentukan oleh pelunasan bea meterai tetapi ditentukan oleh pasal 1320 Kitab Undang-Undang Hukum Perdata. (Supriyanto, 2010)

Bea Meterai berdasarkan Undang-Undang No. 13 Tahun 1985 Tentang Bea Meterai tidak bersifat sebagai penggantian jasa. Ketika pemerintah mengenakan bea meterai atas dokumen tidak ada imbalan secara langsung yang diberikan oleh Pemerintah kepada pembayar bea meterai tersebut. Dalam melakukan suatu perbuatan, adanya suatu keadaan atau peristiwa, tidak diharuskan seseorang membuat suatu dokumen untuk itu. Dengan kata lain bahwa jika tidak dibuat dokumen tidak ada masalah pengenaan bea meterai atau disingkat : tiada dokumen, tiada bea meterai. Objek bea meterai bukanlah perbuatan hukumnya sendiri, seperti perbuatan jual beli, menerima uang, melakukan perborongan pekerjaan dan sebagainya melainkan dokumen yang dibuat untuk membuktikan adanya perbuatan itu seperti surat perjanjian. Sebagaimana disampaikan di atas bahwa objek bea meterai adalah dokumen, tetapi tidak semua dokumen dikenakan bea meterai. Yang dikenakan bea meterai hanya dokumen yang disebutkan dalam pasal 2 Undang-Undang No. 13 Tahun 1985 Tentang Bea Meterai. (Tedjosiswodjo, 1988) Termasuk di dalamnya adalah surat perjanjian.

Surat-surat yang diterbitkan oleh Pemerintah seperti akta kelahiran, surat nikah, talak dan rujuk, surat izin mengemudi, surat tanda nomor kendaraan bermotor, dan berbagai macam surat izin lainnya dari Pemerintah, tidak dikenakan bea meterai, sebab surat-surat yang diterbitkan oleh pemerintah demikian itu adalah bersifat hukum publik dan karena itu bukan objek bea meterai atau dalam artian tidak disebut dalam Pasal 2 Undang-Undang No. 
13 Tahun 1985 Tentang Bea Meterai. Dokumen yang berasal dari Pemerintah tidak dikenakan bea meterai karena menjadi tugas dari pemerintah untuk memberikan pelayanan yang sebaik-baiknya kepada masyarakat.

Menurut Undang-Undang Bea Meterai, surat perjanjian yang dikenakan bea meterai ialah surat perjanjian yang dibuat dengan tujuan untuk dapat dipergunakan sebagai pembuktian mengenai perbuatan, kenyataan atau peristiwa keadaan yang bersifat perdata. Jadi yang dikenakan bea meterai bukan perjanjiannya, melainkan dokumen yang telah dibuat untuk membuktian telah terjadi perbuatan, kenyataan, atau peristiwa keadaan yang bersifat perdata.

Tarif Bea Meterai dibagai menjadi dua, yaitu tarif berdasarkan jenis dokumen dan tarif berdasarkan jumlah nominal yang disebutkan pada dokumen tersebut. Pembagian ini tidak disebutkan secara jelas dalam Undang-Undang No. 13 Tahun 1985 Tentang Bea Meterai, namun secara implisit dapat dilihat dalam Pasal 2 Undang-Undang No. 13 Tahun 1985 Tentang Bea Meterai, yaitu dokumen yang merupakan surat yang dibuat dengan tujuan untuk digunakan sebagai alat bukti di pengadilan, seperti akta notaris dan akta PPAT dikenakan tarif yang sama tanpa melihat isi dari dokumen tersebut.

Besaran nilai bea materai yang di bayarkan dalam pembayaran bea materai itu diwujudkan dengan menempelkan materai atau dengan selembar kertas bermaterai, maka nilai materai atau kertas bermaterai yang digunakan telah di atur dalam Pasal 2 Peraturan Pemerintah Republik Indonesia Nomor 24 Tahun 2000 Tentang Perubahan Tarif Bea Meterai Dan Besarnya Batas Pengenaan Harga Nominal Yang Dikenakan Bea Meterai. (Ermawati, 2017)

Selain tarif bea meterai, bentuk, ukuran dan warna benda meterai juga diatur dalam Peraturan Menteri Keuangan Republik Indonesia Nomor 65/PMK.03/2014 Tentang Bentuk, Ukuran, Dan Warna Benda Meterai, lebih tepatnya pada pasal 1 dan 2 peraturan ini. Aturan ini dikeluarkan dalam rangka meningkatkan pengawasan dan pengamanan terhadap meterai guna menghindari atau mencegah pemalsuan meterai serta untuk memudahkan pengenalan masyarakat awam terhadap ciri-ciri benda meterai yang asli.

\section{Sahnya Surat Perjanjian Tanpa Bea Meterai}

Kehadiran meterai pada setiap dokumen tertentu selalu kita jumpai dalam kehidupan sehari-hari, selain itu juga penggunaan meterai yang paling dirasakan kehadirannya adalah 
penggunaan meterai yang dilakukan oleh masyarakat dalam setiap transaksi yang dilakukan melalui pembuatan surat perjanjian atau kontrak. Untuk dapat memperoleh kepastian hukum suatu surat perjanjian, harus dilakukan menurut ketentuan atau norma-norma hukum yang berlaku dalam masyarakat. Sehingga akibat hukum dari surat perjanjian yang dibuat menimbulkan hak dan kewajiban bagi masing-masing pihak sesuai dengan ketentuanketentuan yang terdapat pada surat perjanjian tersebut. (Tumilaar, 2015)

Surat perjanjian dan perjanjian tentunya adalah dua hal yang tidak dapat dipisahkan saat orang membuat perjanjian. Sedangkan perjanjian sendiri dapat diartikan sebagai suatu perbuatan hukum yang mana seseorang atau lebih membentuk ikatan dengan orang yang lain dengan suatu ikatan di mana kedua belah pihak setuju tanpa adanya paksaan untuk melakukan hal-hal yang telah disepakati bersama. (Palit, 2015)

Surat sebagai alat bukti tertulis di bedakan menjadi akta dan bukan akta. Akta dapat di bedakan menjadi akta autentik dan akta di bawah tangan. Suatu surat agar dapat di katakan sebagai akta harus ditandatangani oleh para pihak, harus dibuat dengan sengaja, dan harus dipergunakan oleh orang untuk keperluan siapa surat itu di buat. Dalam KUH Perdata, ketentuan mengenai akta di atur dalam Pasal 1867 sampai dengan Pasal 1880.

Perbedaan pokok antara akta auentik dengan akta dibawah tangan ialah cara pembuatannya atau terjadinya akta tersebut. Akta autentik cara pembuatannya atau terjadinya akta tersebut dilakukan oleh dan atau dihadapan pejabat pegawai umum (seperti notaris, hakim, panitra dan jurusita. Untuk akta di bawah tangan, cara pembuatannya atau terjadinya tidak dilakukan oleh dan atau di hadapan pejabat pegawai umum, tetapi cukup oleh pihak yang berkepentingan saja.

Salah satu fungsi penting dari akta adalah sebagai alat pembuktian. Akta autentik merupakan alat pembuktian yang sempurna mengikat bagi kedua belah pihak dan ahli warisnya serta sekalian orang yang mendapat hak darinya tentang apa yang dimuat dalam akta tersebut. Akta autentik merupakan bukti yang mengikat, yang berarti bahwa kebenaran dari hal-hal yang tertulis dalam akta tersebut harus diakui oleh hakim, yaitu akta tersebut dianggap sebagai benar-benar selama kebenarannya itu tidak ada pihak lain yang dapat membuktikan sebaliknya. Menurut Pasal 1857 KUHPerdata, apabila akta di bawah tangan tanda tangannya di akui oleh orang terhadap siapa tulisan itu hendak di pakai, maka akta 
tersebut dapat menjadi alat pembuktian yang sempurna bagi orang yang menandatanganinya, serta para ahli warisnya dan orang-orang yang mendapatkan hak darinya.

Pada Undang-Undang Bea Meterai dapat diketahui bahwa surat perjanjian dan suratsurat lainnya yang dibuat dengan tujuan untuk digunakan sebagai alat pembuktian mengenai perbuatan, kenyataan atau peristiwa keadaan yang bersifat perdata maka dikenakan atas dokumen tersebut bea meterai.

Dengan tidak adanya meterai dalam dalam surat perjanjian (contoh pejanjian jual beli), tidak berarti perbuatan hukumnya (perjanjian jual beli) tidak sah, melainkan hanya tidak memenuhi persyaratan sebagai alat pembuktian. Sedangkan sah atau tidaknya suatu perjanjian tersebut tidak ditentukan oleh pelunasan bea meterai melainkan ditentukan oleh Pasal 1320 Kitab Undang-Undang Hukum Perdata. Untuk sahnya persetujuan-persetujuan diperlukan empat syarat, yaitu :

1. Sepakat mereka yang mengikatkan dirinya;

2. Kecakapan untuk membuat suatu perikatan;

3. Suatu hal tertentu;

4. Suatu sebab yang halal.

Persyaratan tersebut diatas berkaitan mengenai subjek maupun objek perjanjian. Persyaratan yang pertama dan kedua berkaitan dengan subjek perjanjian atau syarat subjektif. Persyaratan yang ketiga dan keempat berkaitan dengan objek perjanjian atau syarat objektif. Perbedaan dari kedua persyaratan tersebut dikaitkan dengan masalah batal demi hukumnya (nieteg atau null and ab initio) dan dapat dibatalkannya (vernietigbaar = voidable) suatu perjanjian. Apabila syarat objektif dalam perjanjian tidak terpenuhi maka perjanjian tersebut batal demi hukum atau perjanjian yang sejak semula sudah batal, hukum menganggap bahwa perjanjian tersebut tidak pernah ada. Apabila syarat subjektif tidak terpenuhi maka perjanjian tersebut dapat dibatalkan atau sepanjang perjanjian tersebut belum atau tidak dibatalkan pengadilan, maka perjanjian yang bersangkutan masih terus berlaku. (Gumanti, 2015)

Dengan terpenuhinya empat syarat sahnya perjanjian tersebut di atas, maka suatu perjanjian menjadi sah dan mengikat secara hukum bagi para pihak yang membuatnya. (Suharnoko, 2009) Dalam sahnya suatu perjanjian syarat adanya kesepakatan merupakan hal yang sangat penting untuk terpenuhi. Sepakat ini sendiri ditandai dengan penawaran dan penerimaan dengan cara tertulis, lisan, diam-diam, dan simbol-simbol tertentu. Kesepakatan 
yang dilakukan dengan cara tertulis dapat dilakukan dengan akta autentik dan akta di bawah tangan. (Artadi \& Putra, 2010) Akta dibawah tangan merupakan akta yang dibuat oleh para pihak tanpa perantara seorang pejabat umum. (Rismadewi \& Utari, 2012)

Mengenai kekuatan mengikat para pihak akta di bawah tangan sama halnya dengan akta autentik, jadi apabila perjanjian dibuat secara sah yang artinya tidak bertentangan dengan undang-undang, maka berdasarkan pasal 1338 KUH Perdata, perjanjian tersebut berlaku sebagai undang-undang untuk mereka yang membuatnya, sehingga perjanjian itu tidak dapat ditarik kembali, kecuali berdasarkan persetujuan kedua belah pihak atau berdasarkan alasan-alasan yang ditetapkan undang-undang. (Subekti, 1984) Dengan demikian kini kita telah memahami bahwa Bea Meterai hanyalah sebuah pajak atas dokumen dan tidak ada kaitannya dengan sah tidaknya suatu dokumen.

\section{Kekuatan Yuridis Meterai Apabila Terjadi Sengketa di Pengadilan}

Dalam suatu perkara perdata atau dari keseluruhan tahap persidangan dalam penyeleksian perkara perdata, pembuktian memegang peranan yang sangat penting. Pengertian pembuktian tidak disebutkan secara khusus dalam peraturan perundangundangan, namun terdapat dalam ketentuan pasal 1865 Kitab Undang-Undang Hukum Perdata, menjelaskan :

"setiap orang yang mendalilkan bahwa bahwa ia mempunyai sesuatu hak, atau guna meneguhkan haknya sendiri maupun membantah suatu hak orang lain, menunjuk pada suatu peristiwa, diwajibkan membuktikan adanya hak atau peristiwa tersebut."

Alat pembuktian meliputi :

1. Bukti tertulis,

2. Bukti saksi,

3. Persangkaan,

4. Pengakuan dan sumpah.

Dalam perkara perdata terutama mengenai perjanjian, maka yang dapat dijadikan alat bukti pada persidangan salah satunya adalah bukti tertulis berupa surat perjanjian. Surat tersebut dapat digolongkan dalam pengertian akta, maka surat itu harus ditandatangani, keharusan tanda tangan ini tersirat dalam pasal 1869 Kitab Undang-Undang Hukum Perdata. Keharusan adanya tanda tangan tidak lain bertujuan untuk membedakan antara akta yang satu dengan akta yang lain. Jadi fungsi tanda tangan pada suatu akta adalah untuk memberi 
ciri sebuah akta. Karena identifikasi dapat dilihat dari tanda tangan yang dibubuhkan pada akta tersebut. (Kotimah, 2017)

Alat bukti tulisan atau surat merupakan alat bukti yang paling utama dalam perkara perdata sehingga ditempatkan pada urutan pertama dan paling atas. Dalam lapangan hukum perdata orang-orang yang melakukan perbuatan-perbuatan hukum perdata umumnya sengaja membuat bukti tulisan untuk keperluan pembuktian dikemudian hari. (Syahrani, 2009)

Alat bukti tertulis yang diajukan dalam acara perdata harus dibubuhi meterai agar dapat digunakan sebagai alat bukti Pengadilan. Namun hal ini bukan berarti dengan tiadanya meterai dalam alat bukti tertulis menyebabkan tidak sahnya perbuatan hukum yang dilakukan, hanya akta dari perbuatan hukum yang dilakukan itu tidak memenuhi syarat untuk dapat digunakan sebagai alat bukti Pengadilan. (Waluyo, 1996) Jika suatu surat yang dari semula tidak diberi meterai dan akan dipergunakan sebagai alat bukti di Pengadilan maka permeteraian dapat dilakukan belakangan. (Gani, 2017)

Apabila terjadi sengketa di kemudian hari, surat perjanjian yang belum atau tidak dibubuhi meterai dapat dilakukan pemeteraian kemudian. Aturan mengenai pemeteraian kemudian diatur pada Peraturan Menteri Keuangan Republik Indonesia Nomor 70/PMK.03/2014 Tentang Tata Cara Pemeteraian Kemudian.

\section{Simpulan}

Fungsi bea meterai dalam surat perjanjian adalah agar surat perjanjian tersebut dapat digunakan sebagai alat bukti pembuktian mengenai perbuatan, kenyataan atau peristiwa keadaan yang bersifat perdata.

Dengan tidak adanya meterai dalam dalam surat perjanjian, tidak berarti bahwa perbuatan hukumnya tidak sah, melainkan hanya tidak memenuhi persyaratan sebagai alat pembuktian. Sedangkan sah atau tidak sahnya suatu perjanjian tidak ditentukan oleh pelunasan bea meterai tetapi ditentukan oleh Pasal 1320 Kitab Undang-Undang Hukum Perdata. Untuk sahnya persetujuan-persetujuan diperlukan empat syarat, yaitu : Sepakat mereka yang mengikatkan dirinya, kecakapan untuk membuat suatu perikatan, suatu hal tertentu, suatu sebab yang halal. Dengan terpenuhinya empat syarat sahnya perjanjian tersebut, maka suatu perjanjian menjadi sah dan mengikat secara hukum bagi para pihak yang membuatnya. 
Kekuatan yuridis surat perjanjian yang dilengkapi bea meterai apabila terjadi sengketa di Pengadilan apabila terpenuhinya syarat sahnya perjanjian, maka surat perjanjian tersebut dapat digunakan sebagai alat bukti di Pengadilan.

\section{DAFTAR PUSTAKA}

A. BUKU

Artadi, I. K., \& Putra, I. D. N. R. A. (2010). Hukum Perjanjian Kedalam Perancangan Kontrak. Denpasar: Udayana University Press.

Ermawati, E. (2017). Kekuatan Hukum Akta Perjanjian Tanpa Bea Materai. Institut Agama Islam Negeri Ponorogo.

Gumanti, R. (2015). Syarat Sahnya Perjanjian. Universitas Negeri Gorontalo Press.

Margono. (2019). Asas Keadilan, Kemanfaatan, dan Kepastian Hukum dalam Putusan Hakim. Jakarta: Sinar Grafika.

Rismadewi, A., \& Utari, A. A. S. (2012). Kekuatan Hukum dari Sebuah Akta di Bawah Tangan. Denpasar: Udayana University Press.

Soemitro, R. (1991). Pajak Ditinjau dari Segi Hukum. Bandung: Eresco.

Soemitro, R. (1992). Asas dan Dasar Perpajakan (1st ed.). Bandung: Eresco.

Subekti. (1984). Pokok-Pokok Hukum Perdata. Jakarta: Intermasa.

Suharnoko. (2009). Hukum Perjanjian: Teori dan Kasus. Jakarta: Kencana Prenada Media Group.

Supriyanto, H. (2010). Cara Menghitung PBB, BPHTB, dan Bea Meterai. Jakarta Barat: Indeks.

Syahrani, R. (2009). Materi Dasar Hukum Acara Perdata. Jakarta: Citra Aditya Bakti.

Tedjosiswodjo, L. (1988). Bea Meterai Berdasarkan UU No. 13 TH. 1985. Bandung.

Waluyo, B. (1996). Sistem Pembuktian Dalam Peradilan Indonesia. Sinar Grafika.

\section{B. ARTIKEL JURNAL}

Arief, S. (2011). Penggunaan Bea Meterai Yang Benar Dalam Rangka Sempurnanya Akta Autentik. HUMANITY, 7(1), 44-52.

Gani, E. S. (2017). Keabsahan Perjanjian Kerja Waktu Tertentu Tanpa Meterai Serta Akibat Hukumnya. IAIN Ambon, XIII(1), 15. 
Kotimah, E. K. (2017). Urgensi Tanda Tangan dan Materai dalam Memberikan Kepastian Hukum terhadap Kontrak Waralaba (Franchise). HOLREV, 1(1), 43-63.

Palit, R. C. (2015). Kekuatan Akta di bawah Tangan Sebagai Alat Bukti diPengadilan. Lex Privatum, III(2), 137.

Pamungkas, A. A. (2017). Tinjauan Yuridis Fungsi Bea Materai Dalam Memberikan Kepastian Hukum Terhadap Surat Perjanjian. Jurnal Repertorium, IV(2), 26.

Tumilaar, M. (2015). Fungsi Meterai Dalam Memberikan Kepastian Hukum Terhadap Surat Perjanjian. Lex Privatum, III(1), 59.

\section{UNDANG-UNDANG}

Kitab Undang-Undang Hukum Perdata.

Peraturan Menteri Keuangan Republik Indonesia Nomor 65/PMK.03/2014 Tentang Bentuk, Ukuran, Dan Warna Benda Meterai.

Peraturan Menteri Keuangan Republik Indonesia Nomor 70/PMK.03/2014 Tentang Tata Cara Pemeteraian Kemudian.

Peraturan Pemerintah Republik Indonesia Nomor 24 Tahun 2000 Tentang Perubahan Tarif Bea Meterai Dan Besarnya Batas Pengenaan Harga Nominal Yang Dikenakan Bea Meterai.

Undang-Undang Republik Indonesia Nomor 13 Tahun 1985 Tentang Bea Meterai. 